\title{
3P és a magyar helyi önkormányzatok - Egy jogintézmény alkalmazásának defektusai
}

\author{
közmenedzsment - PPP - közfeladat-ellátás - helyi önkormányzat
}

Az elmúlt években megfigyelhető tendencia, hogy az önkormányzatokra számos közfeladat ellátásának kötelezettsége hárult, gondoljunk csak a Magyarország helyi önkormányzatairól szóló törvény rendelkezéseire. ${ }^{1}$ A gyarapodó feladatokhoz azonban nem feltétlenül társulnak azok ellátásához szükséges források, így az önkormányzatok a jogszabályok, illetve lakosaik által megfogalmazott, feléjük irányuló kötelezettségek ellátására új, az igazgatás weberi szemléletétől gyakran idegen megoldásokra, akár saját költségvetésükön kívül erőforrások felkutatására és igénybevételére kényszerülnek.

Az alternatívnak tekinthető közfeladat-ellátási megoldások között találkozhatunk olyan metódussal, melyben inkább a közjogi, de olyannal is, melyben jelentősebb mértékben képviseltetik magukat a magánjogi elemek. Ilyen, inkább közjoginak tekinthető eszköz például a társulás, a településegyesítés intézménye, melyek elsősorban a közszolgáltatások megszervezése szempontjából optimális településméret elérése végett jönnek létre, ${ }^{2}$ de ugyanilyen, inkább közjogi jellegű metódusoknak tekinthetők a helyi kormányzatok által alkalmazott különböző finanszírozáspolitikai eszközök is. ${ }^{3}$ Előzőek esetén nem tekint a helyi kormányzat a közszektoron kívülre, nem kerülnek bevonásra más, e szektoron kívül eső szereplők, sem azok forrásai. Ellenben léteznek olyan, a közösség igényeinek kielégítését célzó eszközök is, melyek esetén már a közszektoron kívüli aktorok, így azok erőforrásai is bevonásra kerülnek. Ez utóbbi esetekben a közjog kizárólagossága megszűnik, és feltűnnek a magánjogra jellemző sajátos jegyek, mint a mellérendeltség, fő szabály szerint a profitorientáció, a szerződéses szabadság stb. Ilyen a magánjog sajátosságait is felvonultató közfeladat-ellátási eszközök lehetnek a kiszervezés (outsourcing), a kiszerződés (contracing out), a köz- és magánszektor szerződéses megállapodása (Public-Private Partnership PPP) vagy épp az önkéntesség. ${ }^{4}$

* Dr. Varga Judit egyetemi tanársegéd, Debreceni Egyetem Állam- és Jogtudományi Kar Pénzügyi Jog és Közmenedzsment Tanszék, varga.judit@law.unideb.hu. A tanulmány az MTA-DE Közszolgáltatási Kutatócsoport által folytatott „Területi közszolgáltatások szabályozása” című kutatási program (2012-2016) keretében készült.

1 2011. évi CLXXXIX. törvény Magyarország helyi önkormányzatairól (Mötv.), 13. §.

2 Veres Enikő: A városi kormányzás közjogi eszközei. In HoRvátH M. Tamás (szerk.): Jelenségek - A városi kormányzás köréből. Budapest, Dialóg-Campus, 2013, 137-151. 
A PPP tehát csupán egy azon válaszok közül, melyek a korlátozott költségvetési lehetőségek és a változatos, széles körü, valamint magas színvonalon nyújtott közszolgáltatások biztosításában megnyilvánuló társadalmi nyomás között feszülő ellentét feloldására adhatók, és ez csak egy alternatíva, de nem csodaszer. A sikeres alkalmazásához több feltétel együttes érvényesülése szükséges úgy központi, ahogy helyi szinten is.

A PPP-t mint a közösségi igények kielégítésének egyik lehetséges útját hazánkban is több közfeladat-ellátási területen alkalmazták. Épültek ilyen konstrukció keretében például utak, börtönök, kollégiumok. Jelen írás elsősorban a magyar helyi önkormányzatok által megkötött ilyen szerződésekre fókuszál, és a témát szabályozási, jogalkalmazási szempontból, közjogi aspektusból közelíti meg. Olyan kérdésekre keresi többek között a választ, mint hogy milyen tárgykörben, illetve értékben születtek helyi kormányzati szinten ilyen szerződések? Mi indította a települési önkormányzatokat arra, hogy éljenek eme alternatív közfeladat-ellátási lehetőséggel? Hogyan alakult e létesítmények sorsa?

A tanulmány elsősorban a témában korábban született állami számvevőszéki jelentésekre, valamint 2004-ig visszatekintve elfogadott költségvetési, zárszámadási törvényekre és a kapcsolódó egyéb jogszabályok értelmezésére támaszkodik.

\section{A PPP mint eszköz, valamint alkalmazásának indokai}

Ha a PPP lényegét meg kellene ragadni, akkor röviden azt mondhatjuk, hogy ez egy speciális kontraktuális megállapodás, mely valamilyen közösségi igény - ily módon közfeladat - kielégítését szolgálja, s melynek egyik alanya mindenképpen egy közszektorbeli szereplő, tehát valamely állami kormányzati szint ${ }^{5}$ képviselője, amely egy jellemzően a profitorientált magánszektorba tartozó alannyal köt szerződést, melyben a felmerülő kockázatokat a felek megosztják.

A tanulmány alapját képező előbbi fogalomhoz nagyon hasonlóval operál az Európai Bizottság 2004-ben kiadott Zöld Könyve, ${ }^{6}$ mely szerint négy karakteres jellemzője van a PPP-nek. Egyrészt, hogy e szerződések keretében meghatározott projektekre vonatkozóan hosszú távú partneri együttműködés születik a közszektor és a magánszektor között. Másrészt a célzott beruházást legalább részben a magánszektor finanszírozza, a közszektor hozzájárulása esetleges. A magyar terminusban projekttársaságként fordított szereplő meghatározó például a beruházás tervezésben, megvalósításban és finanszírozásban. Továbbá a felmerülő kockázatokon osztoznak a szerződésben részes alanyok. Kappeler és Nemoz 2010-ben megjelent tanulmánya is előbbi definícióra épít. Eszerint a PPP hosszú távra szóló, kockázatmegosztásra épülő szerződéses megállapodás közszektorbeli és magánszektorbeli alanyok között, mely magába foglalja a magánszektor kötelezettségét

5 Tehát akár a központi, akár a helyi kormányzat is alanya lehet.

6 COM(2004) 327 final: Green Paper on Public-Private Partnerships and Community Law on Public Contract and Concessions. Forrás: http://eur-lex.europa.eu/LexUriServ/LexUriServ.do?uri=COM:2004:0327:FIN:EN:PDF (2014. február 10-i letöltés). 
a tervezésre, létesítésre, működtetésre és/vagy karbantartásra, továbbá előbbiek finanszírozására. Ellentételezésként a szerződés futamideje alatt a közszektorbeli alany rendszeres kifizetéseket teljesít a magánszektorbeli alanynak, amely mértéke a magánszektorbeli aktor által nyújtott szolgáltatás színvonalától és minőségétöl függ. ${ }^{7}$ Hasonló módon szedi lajstromba a PPP-szerződések sajátosságait, s ily módon adja meg azok fogalmát Yescombe ${ }^{8}$ is, azzal a különbséggel, hogy jelzi: a magánszektorbeli alanynak a szolgáltatásért fizetett ellenérték nemcsak a vele szerződő közjogi szereplőtől, hanem a szolgáltatást közvetlenül igénybe vevőtől is származhat, aki/amely nem csak közszektorbeli alany lehet. Yescombe felhívja még a figyelmet a szerződéskötés eredményeként létrejövő infrastruktúra tulajdoni viszonyaira is, hisz a létesítmények tulajdonjoga a szerződési futamidő végén maradhat a magánszektorbeli partnernél, de átkerülhet a közszektorbeli alany kezébe is. Előbbiek csupán példák a PPP fogalmának lehetséges meghatározására. Terjedelmi korlátok miatt sajnos nincs mód a tárgyalt szerződéses konstrukció definiálásával foglalkozó nemzetközi szakirodalom mélyebb bemutatására, ahogy a PPP mint gyűjtőfogalom alá tartozó számos szerződéstípus részletes tárgyalására sem, csupán azon jellemzők kiemelésére, hangsúlyozására kínálkozik lehetőség, melyek a legtöbb fogalmi meghatározásban feltünnek.

Ha a PPP-t mint eszközt kellene pozicionálnunk a jogintézmények rendszerében, akkor rá kell jönnünk, hogy egy sokprofilú megoldást üdvözölhetünk a képében. Söt e szerződéskomplexum célja és szereplői miatt már jogterületi besorolása sem magától értetődő, valahol a köz- és a magánjog határmezsgyéjén mozog. Magánjogi jellegét adja a tény, hogy több kontraktuális megállapodás aláíására kerül sor valamennyi PPP konstrukció esetében (pl. építési szerződés, üzemeltetési szerződés stb.), amelyekben a polgári jogban ismert szerződéses alapelvek, s ezzel a részes felek profitorientált érdekei törekszenek kifejezésre jutni. De tekintve, hogy az egyik fél mindig közszektorbeli alany, mely közpénzböl kíván valamilyen közösségi igényt kielégíteni, mely igények megvalósításához a közösségnek érdeke füződik, s az így feltűnő közérdek védelme a szerződéses szabadság feltétel nélküli érvényesülésének gátat szab, megteremtve az egyoldalú kötelezési - közjogi - elemek beépítésének lehetőségét az egyes megállapodásokba.

Mindenekelött közfeladat-ellátási eszközröl van szó, amely távolról sem tekinthető hagyományosnak. A jogintézmény kialakulását és világhódítását alternatív jellegének köszönheti, értve ez alatt, hogy alkalmazása révén az államok és azok kormányzati szintjei saját forrásaikon - a közpénzeken - kívüli pénzügyi és egyéb eszközöket szeretnének bevonni a közfeladatok megvalósításába9 azért, hogy saját költségvetési kiadásaikat csökkenthessék anélkül, hogy a közösség által megszokott (köz)szolgáltatási színvonal romlana. A megoldás célja ily módon a korlátozottan rendelkezésre álló erőforrások lehető leghatékonyabb igénybevétele a

7 Kappeler, Andreas-Nemoz, Mathieau: Public-Private Partnerships in Europe-Before and During the Recent Financial Crisis, 2010. Forrás: http://www.eib.org/epec/resources/efr_epec_ppp_report1.pdf (2013. november 5-i letöltés).

8 Yescombe, E. R.: Public-Private Partnerships - Principles of Policy and Finance. London, Yescombe Consulting Ltd, 2011, 2-3.

9 Horváth M. (2005): i. m., 151. 
közszolgáltatásokkal való ellátottság és a hozzáférhetőség mint eredmény legalább változatlan vagy növekvő színvonalon történő garantálása érdekében. Gyakorlatilag a magánszektorban alkalmazott vezetési technikát - a menedzselést - és annak értékrendszerét közvetíti és teszi felhasználhatóvá a közfeladat-ellátás állami eszköztárában. Azaz a közmenedzsment egyik eszköze is, mely ráadásul privatizációközpontú megoldásnak számít, vagyis nem tipikus állami eszközökkel gazdálkodik a közfeladat-ellátási célok realizálása érdekében. ${ }^{10} \mathrm{E}$ privatizáció-központúság mint tulajdonság egyike azon okoknak, ami miatt a legtöbb kontinentális jogi hagyománnyal rendelkező állam igazgatásszervezési és közfeladat-ellátási gyakorlatába nehezen adaptálható a PPP intézménye, hisz e privatizáció nem jelent ebben az esetben teljes állami kivonulást és állami felelősségvesztést egy-egy szolgáltatás megszervezése kapcsán. Itt tágabb értelemben vett privatizációról van szó, ${ }^{11}$ ahol az állam „beengedi” a közfeladatok ellátásának területére a magánszektort, de a szolgáltatások megszervezéséért, biztosításáért a felelőssége megmarad, ám nem ő lesz az, aki intézményei útján és - optimális esetben - költségvetéséből e szolgáltatásokat ténylegesen nyújtja. Valamint vagyongazdálkodási eszközként is szemlélhető a tárgyalt jogi megoldás tágan értelmezve a vagyon fogalmát, mert még a PPPberuházások első generációi infrastrukturális létesítmények (pl. börtönök, kórházak, oktatási intézmények, utak stb.) kivitelezésére és üzemeltetésére jöttek létre, addig a legújabb generációk már nem materiális létesítmények, mindinkább elvont, de komoly értéket képviselő tudás megszerzésére irányuló kutatás-fejlesztési projektekben jelennek meg. ${ }^{12}$ Közös, hogy valamennyi vagyonelem - materiális és immateriális - létrehozása komoly költségvonzatokkal, bizonytalan és hosszú megtérülési idővel jár, ugyanakkor realizálásuk a közösség egésze számára komoly hasznot hajt. Ezzel egy időben a tárgyalt jogintézmény urbanizációs folyamatokban játszott szerepét is említhetjük, így mint urbanizációs eszközként is ${ }^{13}$ tekinthetünk a PPP-re, hisz elősegítheti a keretében létrejövő infrastrukturális beruházások révén a településrészek és települések közötti kapcsolatok fejlödését, illetve a településeken belüli szolgáltatások színvonalának javulását. Míg a kapcsolati háló - települések közötti kapcsolatok - fejlesztése minden típusú település vonatkozásában értelmezhető és előnyös, addig az utóbbi funkciója, vagyis a településen belüli szolgáltatások színvonalának javítása jellemzően csak egy bizonyos településméret felett lehet kifizetődő.

Több körülmény is motiválhatja a központ és helyi önkormányzatokat, hogy a közösségi igények kielégítésének e módját válasszák. Motiváció lehet az önkormányzatot a szolgáltatásnyújtással összefüggésben terhelő kiadások csökkentése; a szolgáltatásnyújtás kapacitásának javítása, eredményességének fokozása; a tár-

10 Horváth M. Tamás: A közmenedzsment változásai. In Fazekas Marianna (szerk.): A közigazgatás tudományos vizsgálata egykor és ma. Budapest, Gondolat Kiadó, 2011, 94.

11 SAVAS, Emanuel S.: Privatizáció - Hogyan vonuljon ki az állam a gazdaságból? Budapest, Akadémiai Kiadó, 1993, 20-21.

$12 \operatorname{COM}(2013)$ 494/2 Communication from the Commission to the European Parlament, the Council, the European Economic and Social Committee and the Committee of the Regions. Public-privater partnerships in Horizon 2020: powerful tool to deliver on innovation and growth in Europe.

13 BuckHoltz, Alison: Former U.K Secretary of State for International Development reflects on PPPs' role in rapid urbanisation. Handshake, 2012, Issue 4., 13-17. 
sadalom által lényegesnek tekintett beruházások megvalósítása; új munkahelyek teremtése és így a foglalkoztatási viszonyok javítása stb. ${ }^{14} \mathrm{E}$ célok egyik és nem egyedüli elérési módja lehet a PPP, amely kapcsán, pusztán ez ügyletek komplexitásából, időbeliségének hosszából kifolyólag számos kockázattal és buktatókkal kénytelenek szembenézni a részes felek.

Különböző fórumok összegyűjtik és felhívják a figyelmet a PPP alkalmazásának kockázataira, valamint hangsúlyozzák az előkészítés fontosságát. A kockázatoknak és azok megosztásának számos dimenzióit tudjuk megragadni, így például gondolhatunk a politikai, a finanszírozási, a gazdasági, a jogi és szabályozási környezetben rejlö, a müködés és végrehajtásban megbúvó kockázatokra. ${ }^{15}$

Igen hasznos tanácsokat fogalmaz meg John Tizard, a Center of Public Service Partnership ${ }^{16}$ igazgatója kifejezetten a helyi autoritások számára. Ilyen javaslat részéről például, hogy már a beruházás megkezdése előtt tisztázni kell helyi szinten is az elérendő célokat, amelyek megvalósítása érdekében be kívánnak vonni közszektoron kívüli szereplőket a szolgáltatás biztosításába. A szolgáltatással kapcsolatos szükségletek felmérése is kulcsfontosságú, illetve annak átgondolása, hogy az önkormányzat hogyan lenne még képes a felmerülő igények kielégítésére. Nemcsak a gyakorlati megvalósítás során, de már a tervezés idején roppant előnyös, ha ismerik a „külső”, szektoron kívülről érkező befektetők gondolkodásmódját a helyi kormányzatok, hisz a két szereplö között alapvető különbség, hogy míg az egyik a köz szükségleteinek kielégítésén munkálkodik a közfeladatok közösségi forrásokból való finanszírozása útján, addig a másik aktor saját pénzét költi, s magatartását a kereskedelmi célok és a piac törvényszerüségei vezérlik. Hogy az önkormányzatok a legtöbbet hozzák ki egy ilyen együttműködésből, fogyasztóként kell viselkedniük és gondolkodniuk. Ez jelenti egyrészt azt, hogy a közfeladat szolgáltatóinak fizetni kell a nyújtott szolgáltatásért, és egyben ösztönözni kell őket a megfelelő és a még jobb szolgáltatás nyújtására. Tizard tanácsa továbbá, hogy el kell kerülni azokat az alkukat, illetve beszerzési megállapodásokat, melyek alacsony színvonalú szolgáltatás nyújtásához vezetnek. Biztosítani kell a működés, a finanszírozás átláthatóságát és az elszámoltathatóságot. A kötelezettségvállalás modelljének megválasztásába mindenképpen be kell avatni a szélesebb értelemben vett helyi közösségeket - pl. munkavállalókat, helyi vállalkozókat, az ott lakókat stb. - is. ${ }^{17} \mathrm{~A}$ hatékony együttműködés a két szféra között a partneri együttműködés folyamatos építését igényli: állandó együttmüködést, kommunikációt, interakciót, amelyek idő- és pénzigényes tevékenységek.

14 Cuttaree, Vickram-Mandri-Perrott, Cledan: Public-Private Partnerships in Europe and Central Asia. Designing Crisis-Pesislient Strategies and Bankable Projects. Washington DC, The World Bank, 2011, 5-7.

15 Delmon, Jeffrey: Public-Private Partnerships in Infrastructure - An Essencial Guide for Policy Makers. New York (NY), Cambridge University Press, 2011, 95-114.

16 Forrás: http://www.theguardian.com/local-government-network/2011/feb/15/public-private-partnerships-benefitspitfalls (2013. szeptember 23-i letöltés).

17 Forrás: http://www.theguardian.com/local-government-network/2011/feb/15/public-private-partnerships-benefitspitfalls (2013. szeptember 23-i letöltés). 


\section{A magyar helyi önkormányzatok és a PPP}

\subsection{Hazai szabályozás}

A PPP intézményének itthoni szabályozásáról általában elmondható, hogy széttöredezett. Ez az állítás igaz az első szerződések aláíásának időszaka és napjaink vonatkozásában is, hisz ilyen jellegű kontraktusok létrehozása most sem lehetetlen, de tény, hogy a közpolitikai döntéshozók körében mint közfeladat-ellátási alternatíva nem preferált.

Valamennyi PPP-szerződés jogi hátteréül annak idején az államháztartási törvény $^{18}$ (Áht1), a Polgári törvénykönyv, a korábbi közbeszerzési törvény ${ }^{19}$ (Kbt1), egyéb ágazati törvények és az elöbbiekhez kapcsolódó, részletszabályokat tartalmazó kormányrendeletek, országgyűlési határozatok és kormányhatározatok szolgáltak. A szabályozás megjelenését, fejlődését, a jogintézmény alkalmazását tekintve némi megkésettségre lehetünk figyelmesek. ${ }^{20}$

Napjainkra a vonatkozó joganyagban változások álltak be. Egyrészt a korábbi államháztartási törvény helyébe a 2011. évi CXCV. törvény lépett ${ }^{21}$ (Áht2), melynek rendelkezéseit a Magyarország gazdasági stabilitásáról szóló törvény ${ }^{22}$ (Gst.) egészíti ki - amelynek idekapcsolódóan az államadósságra és a hosszú távú állami kötelezettségvállalásra vonatkozó részei relevánsak. Korábbi közbeszerzési törvényünket is új váltotta 2011-ben (Kbt2), ${ }^{23}$ de említhetnénk több, a témát érintő kormányhatározat, valamint rendelet hatályon kívül helyezését is.

Az önkormányzati PPP-szerződések speciális helyzetben voltak, hisz a jogintézmény kapcsán kialakult törvényi szabályozás rájuk nem vonatkozott, csak a központi kormányzat által kötött ügyletekre. ${ }^{24}$ Kezdetben az államigazgatás e szubszuverén ${ }^{25}$ szereplőire nézve a témához tartozóan csupán keret jellegủ szabályozásról beszélhetünk. A speciális fékek, garanciák - így például a hitelfelvételt, valamint hitelállomány méretét korlátozó szabályok - rendszerbe építésének elmaradása komoly, de nem elöreláthatatlan következményekkel járt.

Mi ösztönözte az önkormányzatokat arra, hogy e jogi konstrukció keretében elkötelezzék magukat? A kiváltó okokat az 1990-ben kialakított hazai önkormányzati struktúra jellegzetességeiben, a történelmi helyzet „hozadékában”, a rendszerváltáskor és később érvényesülő gazdasági-politikai folyamatokban, a bankok hitelezési politikájában vagy épp a globalizáció által a nemzetállamok elé állított kihívásokban

18 1992. évi XXXVIII. törvény az államháztartásról.

19 2003. évi CXXIX. törvény a közbeszerzésekről.

20 VARGa Judit: PPP: Volt. Van. Lesz? Gazdaság és Jog, 19. évf. (2011) 2. sz. 19-22.

21 2011. évi CXCV. törvény az államháztartásról.

22 2011. évi CXCIV. törvény Magyarország gazdasági stabilitásáról.

23 2011. évi CVIII. törvény a közbeszerzésröl.

24 Állami Számvevőszék: $A$ köz- és magánszféra együttmüködésével kapcsolatos hazai és nemzetközi tapasztalatok, 2007, 78. Forrás: http://www.theguardian.com/local-government-network/2011/feb/15/publicprivate-partnerships-benefits-pitfalls (2013. október 2-i letöltés).

25 VIGVÁRI András: A kormányzati szintek közötti munkamegosztás a magyar államháztartásban a helyi önkormányzatok pénzügyei. In SIVÁk József-SzEmLÉR Tamás-VIGVÁRI András (szerk.): A magyar államháztartás és az Európai Unió közpénzügyei. Budapest, CompLex Kiadó, 2013, 185. 
és az azokra adott válaszokban kell keresni. ${ }^{26} \mathrm{E}$ széttagolt, sok kisebb településből felépülő rendszerben az egyes helyi kormányzati egységek erősen ragaszkodtak önállóságukhoz, így az egyes közszolgáltatások méretgazdaságossági szempontú megszervezése csak relatíve később indul meg például a társulásokba tömörülés útján, és megindulása után is csupán marginális. Továbbá e központi szint alatti kormányzati egységekre viszonylag sok és nagy költségvonzattal járó feladatokat telepített az önkormányzati törvény (Ötv.), ${ }^{27}$ melyek ellátásának költségeit nem tudta teljes egészében rendelkezésre bocsátani, s melyek biztosításának finanszírozását tekintve számított a helyi autonómiák saját bevételtermelő képességére (pl. helyi adók), mely képesség tekintetében az egyes önkormányzatok között jelentős különbségek mutatkoztak. Akadtak, melyek képesek voltak a közfeladatok finanszírozásának a költségvetési támogatások által nem fedezett részét előteremtetni előbb említett módon, míg mások - és ők voltak a lényegi többség - erre képtelenek voltak, helyette vagyonkészleteik felélésébe és különböző csatornákon, közszektoron kívüli források „felhajtásába” kezdtek (pl. hitel-, kölcsönfelvétel, kötvénykibocsátás stb.). Bárhogy is, a helyi költségvetésekben a müködésre fordított kiadások mellett alig vagy egyáltalán nem jutott felhalmozási, fejlesztési célokra, így az infrastrukturális létesítmények színvonalának romlása általános tendenciává vált.

E forráshiányos állapot leküzdésének, vagy legalábbis káros hatásai kiküszöbölésének lehetőségeként a 2000-es évek elején a központi döntéshozó felfigyelt a nyugati - elsőként angolszász - államokban alkalmazott PPP intézményére, mely első ránézésre az uniós csatlakozás miatt is jelentkező beruházási kényszer, valamint a növekvő nyomást gyakorló „fogyasztói”28 igények és a költségvetési forráshiány között húzódó antinómia feloldására alkalmasnak mutatkozott. Talán ezen a ponton külön ki is emelhetjük, hogy e közmenedzsment-eszköz is hozzávetőlegesen ilyen tájban, az Európai Unió közvetítése révén jelent meg a közfeladat-ellátási eszköztár palettáján a csatlakozó kelet-közép-európai államok számára.

A jogintézmény alkalmazásának lehetőségét kifejezetten a helyi önkormányzatok számára a döntéshozó elsőként 2004-ben ajánlotta fel a sportlétesítmények fejlesztési és működési rendszerének átalakításáról szóló kormányhatározat ${ }^{29}$ elfogadásával, melyben döntött a Sport XXI. Létesítményfejlesztési Program keretében lezajló ingatlanfejlesztés PPP formában történő megvalósításáról. A programnak három alprogramja volt: a „Sporttal a közösségért”, a „Korszerü tornatermet mindenhol” és a „Tanuszodát minden kistérségben” címet viselők. A 2004-es kormányhatározatot aztán további, hasonló célt szolgálók követték. ${ }^{30}$

26 VIGVÁRI András: A magyar önkormányzati rendszer (adósság)csapdában. Fundamentum, 16. évf. (2012) 2. sz. 19-23.

27 1990. évi LXV. törvény a helyi önkormányzatokról.

28 Értve ez alatt a közszolgáltatások igénybe vevőit.

29 1055/2004. (VI. 8.) Korm. határozat a sportlétesítmények fejlesztési és működési rendszerének átalakításáról.

30 Például ilyen a 2039/2005. (III. 23.) Korm. határozat a gyöngyösi sport- és rendezvénycsarnok PPP-konstrukció keretében történő megvalósításáról, illetve a „Sporttal a közösségért” program keretében megvalósuló további hasonló projekthez kapcsolódó eljárásrendröl vagy a 2136/2005. (VII. 15.) Korm. határozat a Dél-Dunántúli 1. Tanuszoda Projekt és a Kozármislenyi Tornaterem Projekt PPP-konstrukció keretében tör- 
Elöbbi sajátosságon kívül közös volt az 1055/2004. (VI. 8.) Korm. határozatot kibontó jogi normákban, hogy mindegyik bevonta az akkor még müködő PPP Tárcaközi Bizottságot, valamint a Nemzeti Sporthivatalt - mint szakmai szervezeteket, amelyeket feladataiknak később különböző minisztériumokba történő integrációjával számoltak fel - a szerződések előkészítésének és megkötésének fázisába.

Mindegyik határozat a költségvetési kiadásoknak szabott egyéves maximumot, bár ezek tartalma nem lett kibontva. Továbbá valamennyi PPP-szerződés hatálybalépésnek feltételül minisztériumi, annak hiányában a kormány jóváhagyását tették. Tekintve, hogy ezek relatíve kisebb projektek, ezért az Áht1 2003-as módosítása után - mely az 50 milliárd forintot elérő vagy azt meghaladó többéves fizetési kötelezettséggel járó szerződések aláírása előtt a kormányt az országgyűlés felhatalmazásának megszerzésére kötelezte - sem volt szükség az országgyülés jóváhagyására. ${ }^{31}$

Közös még, hogy mindegyik kormányhatározat kiemelte a szerződéses felek közötti kockázatmegosztás fontosságát, vagyis hogy az feleljen meg az Eurostat vonatkozó szabályainak, amely értelmében csak akkor minősül egy beruházás PPP-nek, s csak akkor nem terheli meg a költségvetést, ha a szerződéses megállapodásban a magánszektorbeli alany viseli az építési kockázatot, valamint a rendelkezésre állási vagy keresleti kockázatok közül legalább egyet. ${ }^{32} \mathrm{Az}$ Eurostat határozata értelmében tehát a szerződésben részes felek közötti megfelelő kockázatallokáció esetén el lehetett kerülni e kiadások költségvetésben történő szerepeltetésének kötelezettségét, ami így úgy adott lehetőséget az államadósságra és az államháztartási egyensúlyra vonatkozó konvergenciakritériumoknak való megfelelésre, hogy engedte az állami költekezést.

\subsection{Ellentmondások a PPP hazai alkalmazása körében}

Az Állami Számvevőszék (ÁSZ) 2009-ben elkészített jelentésében górcső alá vette a hazai önkormányzatok által kötött PPP-szerződéseket, és számtalan problémát tárt fel az említett kontraktusokat érintően. Az ÁSZ által készített dokumentumban szereplő problémákat a következő csoportokba rendezhetjük.

Említhetjük azokat a gondokat, melyek a jogi konstrukció hazai szabályozottságából, illetve annak elmaradásából fakadnak. ${ }^{33}$ A hosszú távú állami kötelezettsé-

ténő megvalósításáról, illetve a „Tanuszodát minden kistérségben” és a „Korszerű tornatermet mindenhol” program keretében megvalósuló további projektekhez kapcsolódó eljárásrendről.

31 VARGA Judit: Hosszú távú kötelezettségvállalás, és tárgyéven túli költségvetési tervezés szabályozásának alakulása államháztartási törvényünkben. In P. SzABó Béla-Szemesı Sándor (szerk.): Profectus in Litteris V. Debrecen, Dela, 2013, 363-370.

32 New decision of Eurostat on deficit and debt. Treatment of Public-Private Partnerships. In Eurostat News Release STAT/04/18., 11. February 2004. Forrás: http://epp.eurostat.ec.europa.eu/cache/ITY_PUBLIC/211022004-AP/EN/2-11022004-AP-EN.HTML (2013. november 20-i letöltés).

33 Állami Számvevőszék: Jelentés a Sport XXI. Létesítményfejlesztési Program keretében támogatott önkormányzati PPP-beruházások megvalósitásának és önkormányzati feladatok ellátásra gyakorolt hatásának ellenörzéséröl, 2009, 16, 18, 25. Forrás: http://www.asz.hu/jelentes/0919/jelentes-a-sport-xxiletesitmenyfejlesztesi-program-kereteben-tamogatott-onkormanyzati-ppp-beruhazasok-megvalositasanak- 
gekre vonatkozó kormányrendelet, ahogy az államháztartási, illetve a helyi önkormányzatokról szóló törvény sem tartalmazott előírásokat a helyi kormányzati szinten születő ilyen megállapodásokra. A PPP alkalmazását érintően a tapasztalatlanság és a szabályozásban meglévő bizonytalanság, illetve hiányosságok napjainkban is meghatározzák a rendszert. Ráadásul a korábban müködő PPP Tárcaközi Bizottság - melynek feladata a PPP-szerződések szakmai véleményezésében merült ki, s amelyet 2009 októberével meg is szüntettek - hatáskörét nem terjesztették ki a helyi önkormányzati szinten létrejött ilyen megállapodásokra, továbbá, ha hatásköre ki is terjedt volna rájuk, nem lett volna kapacitása az előbbi konstrukciók monitoringjának elvégzésére.

A jogintézmény itthoni alkalmazása kapcsán vannak olyan problémák, amelyek a helyi önkormányzatok szándékából és a központi kormányzat támogatási politikájából adódtak. ${ }^{34}$ Jelesül a PPP alkalmazásának elsődleges célja jellemző módon az volt, hogy garantálni lehessen az egyes projektekre szánt központi kiadások államháztartási rendszeren kívüli elszámolását. Továbbá nem túl pozitív körülmény, hogy a helyi autoritások mintegy kényszerpályára voltak állítva azáltal, hogy csak abban az esetben részesültek a Sport XXI. Létesítményfejlesztési Programból sportlétesítmények építésére, fejlesztésére központi támogatásban, ha a PPP jogintézményét választották a beruházás megvalósításának formájául. Az ÁSZ vizsgálatai során fény derült rá, hogy az önkormányzatok, amennyiben arra a szükséges források korábban is rendelkezésükre álltak volna, akkor megvalósítják a sportberuházásokat. Így feltételezhető, hogy az önkormányzatokat nem csak gazdaságossági, hatékonysági szempontok motiválták, amikor belevágtak az említett projektekbe. A hazai PPP-beruházások kapcsán visszatérő probléma, ami megjelenik helyi kormányzati szinten is, hogy elmaradt azoknak a kimutatásoknak az elkészítése, melyekben ugyanazon beruházás PPP-formátumú és hagyományos állami kivitelezését vetették volna össze. A kormányzati támogatási politika gyengesége, hogy elmaradt a gazdaságpolitika egészébe illeszkedő PPP-stratégia megfogalmazása központi szinten, továbbá, hogy nem lehetetlenítette el a létesítményfejlesztési programban a részvételt, ha a pályázó önkormányzat működési forráshiánnyal küzdött, vagy épp, ha nem sokkal korábban önhiki-ben részesült. Ugyancsak a kormányzati támogatási politika indokolatlan lazaságát jelzi, hogy nem füzött negatív következményeket ahhoz, ha az egyes önkormányzatok az eredetileg támogatott mintaprojektekhez képest több funkciót is ellátó létesítmény megvalósítására tettek közzé ajánlati felhívást. Ezek a problémák a szerződések előkészítése kapcsán jelentettek komoly gondot. Ugyancsak ehhez az időbeli fázishoz kapcsolható a PPP-k megvalósítása érdekében lefolytatott közbeszerzési eljárások során érzékelhető visszásságok. Az ÁSZ megállapította, hogy a vizsgált önkormányzatok 93\%-ában nem alakult ki verseny az ajánlattevők között. További probléma, hogy az önkormányzatok ajánlati felhívása gyakran a program által támogatotthoz képest bővebb funkciót ellátó létesítményekre szóltak, melyek többletköltségeinek fedezetéül szintén a központi

es-onkormanyzati-feladatok-ellatasara-gyakorolt-hatasanak-ellenorzeserol/0919j000.pdf (2013. október 5-i letöltés).

34 Állami Számvevőszék (2009): i. m., 15-16, 18. 
költségvetés előbb említett fejlesztési programja szolgált. Több eljárási szabálysértésre is felhívta az ÁSZ a figyelmet, melyek főleg a megfelelő dokumentáció, illetve a szerződések módosítása esetén a közzététel elmaradásában nyilvánult meg. ${ }^{35}$

A megkötött szerződések tartalmát illetően a szolgáltatási díjak különböző funkciót betöltő tételeinek el nem különítése; a közcélú igénybevételi arány megállapításának többszöri elmaradása, mely az állam által fizetendő szolgáltatási díj egyértelmú meghatározását hivatott biztosítani; illetve a központi kormányzat tudta nélkül az önkormányzatok és az üzemeltetők által megkötött „,háttérszerződések” jelentették a legsúlyosabb problémákat. $E$ „háttérszerződésekben” az önkormányzatok az üzemeltetési feladatok és a rendelkezésre állási kockázatok egy részét mint a magánpartnerek alvállalkozói magukra vállalták. Ez pedig azzal járhat, hogy az Eurostat minősítése szerint említett PPP-formációk nem tekinthetők tényleges PPP-szerződésnek, illetve a rendelkezésre állási és keresleti kockázatok közszféra irányába történő eltolódásai korrupciós kockázatot hordozhatnak. ${ }^{36}$

Az önkormányzati PPP-megállapodások működtetése során, azaz a végrehajtás fázisában is adódtak nehézségek. Ezek egy része a gazdasági környezet kedvezőtlen megváltozásából, míg másik része abból a körülményből fakadt, hogy a különböző szintủ kormányzati döntéshozóknak nem sikerült a profitorientált magánszférabeli alanyok gondolkodásmódját kellőképpen elsajátítaniuk. Előbbire példa, hogy a szolgáltatási díj csökkentésének szankciójával nem élt a közszféra a nem megfelelő vagy nem határidőre történő teljesítés esetén. A gazdasági környezet kedvezőtlen változása kapcsán elsősorban a hitelválságra kell gondolni, hisz a PPP-szerződések megvalósítása érdekében föleg devizaalapú hitelek születtek; továbbá a beálló gazdasági recessziót is számításba kell venni mint beruházást drágító körülményt. ${ }^{37}$

A szerződésmenedzsment utolsó fázisában, az ellenőrzés során is adódtak hazánkban gondok. Ilyennek tekinthető például, hogy a helyi PPP-beruházások évenkénti figyelemmel kísérése nem volt biztosított - a MÁK ezeket nem követte le törvényi kötelezés hiányában - egyrészt azért, mert az önkormányzatok ezeket a szerződéseket nem szerepeltették könyveléseikben mint hosszú lejáratú kötelezettségvállalást. Másrészt a vagyonnyilvántartáshoz szükséges adatokat a magánpartnerek kezelték, akiket nem kötelezett jogszabály adatszolgáltatásra. Továbbá a nyilvántartási értékek egységes meghatározása is hiányzott. Ráadásul a minisztérium a helyszíni ellenőrzés jogáról részben le is mondott a szolgáltatási szerződésekben. De említhetjük az ellenőrzés során kialakuló összeférhetetlenséget is, mint ellentmondást, amikor az ellenőrzést, és mint alvállalkozó az üzemeltetést is az önkormányzat végezte. ${ }^{38}$

35 Állami Számvevőszék (2009): i. m., 14, 17-18.

36 Állami Számvevőszék (2009): i. m., 20-21, 23-24.

37 Állami Számvevőszék (2009): i. m., 22.

38 Állami Számvevőszék (2009): i. m., 19, 22, 25. 


\subsection{A magyar helyi önkormányzati PPP-beruházásokat illető becslések}

Ahogy az fentebb említésre került, e megállapodások egységes rendszerben, átlátható formában történő nyilvántartására nem volt egyetlen szervezetnek, intézménynek sem törvényi kötelezettsége, így a transzparencia hiánya erősen mutatkozik.

Információk csupán az ÁSZ 2009 júliusában kiadott jelentéséből állnak rendelkezésünkre, amely gyakorlatilag a 2008 végéig fennálló állapotokról szolgáltat hiteles adatokat. A későbbi eseményekről csupán töredékinformációk állnak a rendelkezésünkre, mint a kormányzati portálok, illetve más médiumok hírközlései, a központi költségvetési és azok végrehajtásáról szóló törvények, továbbá a helyi önkormányzatok költségvetésében foglaltak, melyekből részletes, objektív kép nehezen vázolható fel. Ennek oka, hogy a költségvetési, zárszámadási törvények nem teszik lehetővé annak vizsgálatát, hogy a különböző projektekre mekkora összegű központi forrást bocsátott a döntéshozó rendelkezésre, hisz az előirányzatok nincsenek részletezve, összevontan szerepelnek. Ez a probléma ugyanúgy jelentkezik a helyi önkormányzatok költségvetési és zárszámadási rendeleteiben is. Ráadásul az egyes települések költségvetései nagyon változatos képet mutatnak, akár formailag, akár az előirányzatok megnevezését tekintve.

A hiányos nyilvántartások miatt áll elő az a helyzet, hogy a 1. mellékletben jelzett PPP-ben érintett önkormányzatok listája nem teljes, hisz csupán a 2009. március 25-ig fennálló állapotokat mutatja, tehát a PPP-konstrukciókat elutasító közpolitikai álláspont kialakulásáig - 2010 második feléig - több mint egy év eltelt, mely idő alatt születhettek, és a jelek szerint születtek is (pl. Törökbálinton) újabb ilyen megállapodások. Az ÁSZ által ellenőrzött projektekben az építési kockázat, Mohács kivételével, a magánpartnert terhelte. Ugyancsak a magánszférabeli alanynál jelentkeztek a rendelkezésre állási kockázatok is, míg a keresleti kockázatokat a közszféra viselte. A szerződési idő végén pedig az önkormányzatok egy előre meghatározott, jelképes összegért cserébe megvásárolhatták volna a létesítményeket, így szerezve rajtuk tulajdont. ${ }^{39}$ Előbbiek alapján ezek a PPP-kontraktusok BOT (build-operate-transfer) szerződések voltak, ahol a közszektorral szerződő fél létesíti, müködteti az infrastruktúrát, majd átruházza annak tulajdonjogát.

A Sport XXI. Létesítményfejlesztési Programra összesen 184 önkormányzat nyújtotta be pályázatát. A legtöbben - összesen 145 - tornatermek építését célozták meg, mely közül 18 településen indultak meg a munkálatok, a többiek visszaléptek. Népszerüségét tekintve a tanuszoda építésére kiírt pályázat volt a második, hisz ez iránt 66 önkormányzat érdeklődött, melyek közül szintén 18-ban indult meg a szerződéskötési eljárás, a maradék 48 visszakozott. Már csak a beruházások méretéből fakadóan a legkevesebben a „Sporttal a közösségért” alprogramban pályáztak, öszszesen 10 önkormányzat, melyek közül 1 volt az, ahol megindult a projekt. 


\section{1. táblázat}

A Sport XXI. Létesítményfejlesztési Programból visszalépett önkormányzatok - A visszalépés okai (a darabszám az önkormányzatok számát jelöli, a százalékos adatokat pedig egész számra kerekítettük)

\begin{tabular}{|c|c|c|c|c|c|}
\hline \multirow[b]{2}{*}{ A visszalépés oka } & \multicolumn{3}{|c|}{ A beruházás célja } & \multicolumn{2}{|c|}{ Összesen } \\
\hline & Tornaterem & Tanuszoda & $\begin{array}{l}\text { Sportcsarnok/ } \\
\text { fedett uszoda }\end{array}$ & $d b$ & $\%$ \\
\hline Közbeszerzés & 17 & 14 & 7 & 38 & 21 \\
\hline $\begin{array}{l}\text { Önkormányzat gazdasági } \\
\text { helyzete }\end{array}$ & 48 & 11 & - & 59 & 32 \\
\hline $\begin{array}{l}\text { A szerződés aláírása } \\
\text { elmaradt }\end{array}$ & 14 & 6 & 1 & 21 & 11 \\
\hline $\begin{array}{l}\text { Nem készült vagy nem } \\
\text { fogadták el a projekttervet }\end{array}$ & 13 & 6 & - & 19 & 10 \\
\hline Egyéb & 15 & 4 & 1 & 20 & 11 \\
\hline Nem szolgáltatott adatot & 20 & 7 & - & 27 & 15 \\
\hline Összesen & 127 & 48 & 9 & 184 & 100 \\
\hline
\end{tabular}

Forrás: saját szerkesztés, ÁSZ, 2009.

Ha az önkormányzatok visszalépésének indokait vizsgáljuk, akkor az 1. táblázatból láthatjuk, hogy bár feltűnően nagy arányban nem szolgáltattak adatot az önkormányzatok visszalépésük okáról, akik azonban megtették, azok föleg gazdasági helyzetük, illetve a közbeszerzések kapcsán keletkező problémák miatt nem vágtak bele a beruházásokba.

A kormányzat 2010-ben kezdte meg a PPP-konstrukciók felülvizsgálatát hazánkban. Később döntött ezek támogatásának megszüntetéséről - így ezt követően újabb ilyen szerződés aláírására nem került sor -, majd állami kivásárlásáról határozott, azonban előbbi folyamat a létesítmények méretéből, tehát a korábbi befektetések költségességéből adódóan, és persze a költségvetési lehetőségek korlátozottsága okán lassan haladt előre. A folyamat két évvel ezelőtt az önkormányzati beruházások kiváltásával indult meg valószínüleg azért, mert méretüket tekintve ezek voltak a legkisebbek, ugyanakkor arányaiban az egyes önkormányzatok müködését lényegesen megnehezítették, például Kiskunfélegyháza és Magyaratád a területükön megvalósult PPP-projektek megindulása után kénytelen volt önhiki-támogatásért folyamodni. ${ }^{40}$

A kormányzati hírportálok 2012-ben 17 sportberuházás kiváltásáról számoltak be, mely létesítmények tulajdonjogát a helyi önkormányzatok kapták meg, amelyek rendeltetésszerü üzemeltetéséről az önkormányzatoknak kell gondoskodniuk. A 17 beruházásból 9 volt tornateremre irányuló, melyekben a következő önkormányzatok voltak érintve: Balassagyarmat, Nagybajom, Somogyján, Szenna, Felsőzsolca, Magyaratád, Dédestapolcsány, Cigánd és Csurgó. A kiváltott további 8 szerződés

40 Állami Számvevőszék (2009): i. m., 60. 
uszoda létesítésére irányult, melyekben Nagyatád, Marcali, Iváncsa, Tab, Bicske, Tata, Mohács és Lengyeltóti vettek részt. A 17 darab 2012 végén kiváltott konstrukció mellett még kettőről folytak tárgyalások ugyanebben az évben - Törökbálinton, ${ }^{41}$ Hódmezővásárhelyen. 2013 augusztusában pedig megtörtént a bátaszéki uszoda kivásárlása és önkormányzati tulajdonba adása. ${ }^{42}$

\section{Zárógondolatok}

2004-ben a Gazdasági és Közlekedési Minisztérium által közzétett PPP-kézikönyv, illetve a témát érintően korábban az ÁSZ által készített jelentések is tartalmaztak észrevételeket, figyelemfelhívó javaslatokat a PPP jogintézményének alkalmazására vonatkozóan. Ezek azonban a gyakorlati alkalmazás során nem vagy csak töredékesen kerültek adaptálásra, ahogy azt a helyi önkormányzati sportlétesítmények példái is mutatják.

A PPP-ben kivitelezett sportberuházások, ahogy más privatizáció-központú menedzseri megoldások hazai alkalmazása is, leképezik a közfeladat-ellátásba épített menedzseri eszközök „sorsát”, torzulásait a kelet-közép-európai államokban. ${ }^{43}$ Elöbbi eszközök deformitását egyrészt az okozta, hogy a legtöbb államban a rendszerváltás során egy az egyben a nyugati mintákat emelték át, többek között a szolgáltatásszervezési megoldások körébe is, azonban eme intézmények továbbra is "rendszeridegenek" maradtak. Elég, ha a nyugaton organikus fejlődés eredményeként megszilárdult garanciarendszerre (pl. fogyasztóvédelem, szabályozó hatóságok stb.), illetve annak itthoni hiányára gondolunk, ${ }^{44}$ mely garanciarendszer nem léte más területeken is éreztette hatását és növelte az ország globális világgazdasági folyamatokkal szembeni kiszolgáltatottságát. A PPP és a hozzá hasonló privatizációcentrikus közmenedzsment eszközök ráadásul angolszász gyökerekkel bírnak, melyek alkalmazása kontinentális jogi hagyományokkal rendelkező államokban a közjog és magánjog - előbbi országcsoportra jellemzőhöz képest - jóval élesebb elkülönítése miatt külön problémás, és újabb nehézségek forrása lehet. ${ }^{45}$

Előbbi kihívások okán, de hangsúlyosan a 2008-as hitelválság vizsgált területekre történt begyürüzése és a több oldalról érkező költségvetési nyomás miatt, talán érthető, hogy a közpolitikai döntéshozók szemlélete megváltozott az előbbi konstrukciók támogatása kapcsán, illetve az, hogy azóta a közmenedzsmentre jellemző megoldások föleg „az állami eszközökkel való sáfárkodás közpolitikai”46 céljai

\footnotetext{
41 Állami Számvevőszék: Jelentés a helyi önkormányzatok pénzügyi-gazdálkodási helyzetének, szabályosságának ellenőrzéséröl - Törökbálint, 2013.

Forrás: http://www.asz.hu/jelentes/13096/jelentes-az-onkormanyzatok-penzugyi-gazdalkodasi-helyzetenekszabalyossaganak-ellenorzeserol-torokbalint/13096j000.pdf (2013. október 20-i letöltés).

42 Forrás: http://mno.hu/gazdasag/ujabb-ppp-s-sportletesitmenyt-valtott-ki-az-nfm-1177326 (2013. szeptember 27-i letöltés).

43 HoRváth M. (2005): i. m., 77-82.

44 HoRváth M. (2011): i. m., 90-91.

45 ZuPKó Gábor: Közigazgatási reformirányok az ezredfordulón. Budapest, Századvég Kiadó, 2002.

46 Horváth M. (2011): i. m., 94.
} 
megvalósítása érdekében kerülnek alkalmazásra például társulások vagy különböző indirekt kormányzati beavatkozások (pl. támogatások, adókedvezmények stb.) formájában.

Összességében az ÁSZ által készített különböző jelentésekből, illetve a nemzetközi színtéren zajló eseményekből - az Európai Bizottság 2013-ban közzétett közleményeiből; különböző országjelentésekből (lásd pl. European Public-Private Partnership Review); Európai Beruházási Bank, ${ }^{47}$ EPEC (European PPP Expertise Center) által kiadott összefoglalókból ${ }^{48}$ - a PPP mint jogi konstrukció vagy közfeladat-ellátási eszköz itthoni kudarca valószínűsíthetően nem annak alkalmatlanságára, hanem a hazai alkalmazásában hemzsegő defektusokra vezethető vissza, mint a nem megfelelő előkészítettség, az összehasonlító költségkalkuláció vagy a piaci igényeket előzetesen felmérő kimutatások elmaradása, a túlzottan megengedő szabályozás, a megfelelő monitoringot biztosító garanciarendszer hiánya és így a transzparencia elmaradása stb.

\section{Abstract}

It's a huge challenge to qualify the operation of an organised society's needs especially because of the limited resources. The task above has put pressure on the states since the middle of the $X X^{\text {th }}$ century. To solve the pervious problem the states started to find new, non-traditional, alternative tools, legal institutions which are able to include other sectors resource (e. g. private sector's) into the provision of the public duties. One of these alternative legal institutions is the Public-Private Partnership (PPP). The study tries to answer the question: what results has adapted this legal tool by the Hungarian local governments.

47 Például: GeORg Interst: Private Infrastructure Finance and Investment in Europe. European Investment Bank, 2013. Forrás: http://www.eib.org/attachments/efs/economics_working_paper_2013_02_en.pdf (2013. október 24-i letöltés).

48 Például: European PPP Expertise Center: Market Update - Review of the European PPP Market in 2012, 2012. Forrás: http://www.eib.org/epec/resources/epec_market_update_2012_en.pdf (2013. október 25-i letöltés). 


\section{Mellékletek}

\section{2. táblázat}

Önkormányzati PPP-projektek 2009. március 25-ig

\begin{tabular}{|c|c|c|c|}
\hline \multicolumn{4}{|c|}{ „Korszerü tornatermet mindenhol” alprogram } \\
\hline & $\begin{array}{c}\text { szerződéskötés } \\
\text { fázisa }\end{array}$ & épül & üzemel \\
\hline Balassagyarmat Város Önk. & & & $x$ \\
\hline Nagybajom Város Önk. & & & $\mathrm{x}$ \\
\hline Somogyjád Község Önk. & & & $\mathrm{x}$ \\
\hline Nagykáta Város Önk. & & & $x$ \\
\hline Szenna Község Önk. & & & $x$ \\
\hline Miskolc Város Önk. & & $x$ & \\
\hline Felsőzsolca Város Önk. & & & $\mathrm{x}$ \\
\hline Pécel Város Önk. & $x$ & & \\
\hline Kiskörös Város Önk. & & & $x$ \\
\hline Magyaratád Község Önk. & & & $\mathrm{x}$ \\
\hline Dédestapolcsány Község Önk. & & & $x$ \\
\hline Aba Nagyközség Önk. & $x$ & & \\
\hline $\begin{array}{l}\text { Hódmezővásárhely } \\
\text { Megyei Jogú Város Önk. }\end{array}$ & & & $\mathrm{x}$ \\
\hline Hit Gyülekezete & & & $x$ \\
\hline Kozármisleny Város Önk. & & & $\mathrm{x}$ \\
\hline Cigánd Nagyközség Önk. & & & $\mathrm{x}$ \\
\hline Hit Gyülekezete & & & $\mathrm{x}$ \\
\hline Csurgó Város Önk. & & & $\mathrm{x}$ \\
\hline Összesen & 2 & 1 & 15 \\
\hline \multicolumn{4}{|c|}{ „Tanuszodát minden térségben” alprogram } \\
\hline Ibrány Város Önk. & & & $x$ \\
\hline Újfehértó Város Önk. & & $x$ & \\
\hline Nagyatád Város Önk. & & & $x$ \\
\hline Marcali Város Önk. & & & $x$ \\
\hline Iváncsa Község Önk. & & $x$ & \\
\hline Tab Város Önk. & & & $x$ \\
\hline Bicske Város Önk. & & $x$ & \\
\hline Tata Város Önk. & & & $x$ \\
\hline Szigetvár Város Önk. & & & $x$ \\
\hline
\end{tabular}




\begin{tabular}{|c|c|c|c|}
\hline \multicolumn{4}{|c|}{ „Tanuszodát minden térségben” alprogram } \\
\hline Bácsalmás Város Önk. & & & $\mathrm{x}$ \\
\hline Mohács Város Önk. & & & $x$ \\
\hline Aba Nagyközség Önk. & $?$ & & \\
\hline Ózd Város Önk. & & & $x$ \\
\hline Bátaszék Város Önk. & & & $x$ \\
\hline Kiskörös Város Önk. & & $x$ & \\
\hline Lengyeltóti Város Önk. & & & $x$ \\
\hline Acsa Nagyközség Önk. & & & $x$ \\
\hline Gönc Város Önk. & & & $\mathrm{x}$ \\
\hline Összesen & 1 & 4 & 13 \\
\hline \multicolumn{4}{|c|}{ „Sporttal a közösségekért” alprogram } \\
\hline Kiskunfélegyháza & & & $x$ \\
\hline Összesen & & & 1 \\
\hline $\begin{array}{l}\text { ÖSSZESEN } \\
\text { (valamennyi projekt) }\end{array}$ & 3 & 5 & 29 \\
\hline
\end{tabular}

Forrás: saját szerkesztés, ÁsZ, 2009.

\section{3. táblázat}

Hazai önkormányzati PPP-konstrukciókra teljesített/előirányzott központi költségvetési támogatások 2004-2013 között

\begin{tabular}{|c|c|c|c|c|c|}
\hline \multirow{2}{*}{ Év } & \multicolumn{2}{|c|}{ Forrás } & \multirow{2}{*}{$\begin{array}{l}\text { Felelős } \\
\text { miniszté- } \\
\text { rium }\end{array}$} & \multirow{2}{*}{ Az előirányzat megnevezése } & \multirow{2}{*}{$\begin{array}{l}\text { Teljesített } \\
\text { vagy elö- } \\
\text { irányzott } \\
\text { összeg } \\
\text { (millió Ft) }\end{array}$} \\
\hline & $\begin{array}{l}\text { ktv- } \\
\text { tv. }\end{array}$ & $\begin{array}{l}\text { zársz. } \\
\text { tv. }\end{array}$ & & & \\
\hline 2004 & & $x$ & ICsSzEM & Sportfejlesztés - Sport XXI. Program & 718,4 \\
\hline 2005 & & $x$ & BM & Sport XXI. Létesítményfejlesztési Program & 1200 \\
\hline 2006 & & $x$ & Ӧтм & Sport XXI. Létesítményfejlesztési Program & 2904 \\
\hline 2007 & & $x$ & ÖTM & Sport XXI. Létesítményfejlesztési Program & 509,5 \\
\hline 2008 & & $x$ & ÖM & $\begin{array}{l}\text { Sportlétesítmények PPP-konstrukcióban } \\
\text { történő fejlesztése }\end{array}$ & 1400 \\
\hline 2009 & & $x$ & ÖM & $\begin{array}{l}\text { Sportlétesítmények PPP-konstrukcióban } \\
\text { történő fejlesztése }\end{array}$ & 929,5 \\
\hline 2010 & & $x$ & NFM & $\begin{array}{l}\text { Sportlétesítmények PPP-konstrukcióban } \\
\text { történő fejlesztése }\end{array}$ & 1339 \\
\hline 2011 & & $x$ & NFM & $\begin{array}{l}\text { Sportlétesítmények PPP-konstrukcióban } \\
\text { történő fejlesztése }\end{array}$ & 1522 \\
\hline
\end{tabular}




\begin{tabular}{|c|c|c|c|c|c|}
\hline \multirow{2}{*}{ Év } & \multicolumn{2}{|c|}{ Forrás } & \multirow{2}{*}{$\begin{array}{l}\text { Felelős } \\
\text { miniszté- } \\
\text { rium }\end{array}$} & \multirow{2}{*}{ Az előirányzat megnevezése } & \multirow{2}{*}{$\begin{array}{l}\text { Teljesített } \\
\text { vagy elö- } \\
\text { irányzott } \\
\text { összeg } \\
\text { (millió Ft) }\end{array}$} \\
\hline & $\begin{array}{c}\text { ktv- } \\
\text { tv. }\end{array}$ & $\begin{array}{c}\text { zársz. } \\
\text { tv. }\end{array}$ & & & \\
\hline \multirow[b]{2}{*}{2012} & \multirow[b]{2}{*}{$\mathrm{x}$} & & \multirow[b]{2}{*}{ NFM } & $\begin{array}{l}\text { PPP-programok: Oktatási, } \\
\text { kulturális és sportprogramok }\end{array}$ & 21061,3 \\
\hline & & & & $\begin{array}{l}\text { PPP-konstrukcióban létrehozott } \\
\text { beruházások megvásárlásával } \\
\text { és befejezésével kapcsolatos kiadások }\end{array}$ & 15000 \\
\hline 2013 & $x$ & & NFM & $\begin{array}{l}\text { PPP-programok: Oktatási, } \\
\text { kulturális és sport PPP-programok }\end{array}$ & 21102 \\
\hline
\end{tabular}

Forrás: saját szerkesztés. ${ }^{49}$ Rövidítések: ktv-tv. - költségvetési törvény; zársz. tv. - zárszámadási törvény. ICsSzEM - Ifjúsági, Családügyi, Szociális és Esélyegyenlőségi Minisztérium; BM - Belügyminisztérium; ÖTM - Önkormányzati és Területfejlesztési Minisztérium; ÖM - Önkormányzati Minisztérium; NFM Nemzeti Fejlesztési Minisztérium.

49 Az adatok forrása a 2005. évi CXVIII. törvény a Magyar Köztársaság 2004. évi költségvetéséröl és az államháztartás hároméves kereteiröl szóló törvény végrehajtásáról, a 2006. évi XCIX. törvény a Magyar Köztársaság 2005. évi költségvetésének végrehajtásáról, a 2007. évi CXXVIII. törvény a Magyar Köztársaság 2006. évi költségvetésének végrehajtásáról, a 2008. évi LXXVIII. törvény a Magyar Köztársaság 2007. évi költségvetésének végrehajtásáról, a 2009. évi CXXIX. törvény a Magyar Köztársaság 2008. évi költségvetésének végrehajtásáról, a 2010. évi XCVIII. törvény a Magyar Köztársaság 2009. évi költségvetésének végrehajtásáról, a 2011. évi CLXXXVIII. törvény Magyarország 2012. évi központi költségvetéséröl, a 2011. évi CXXXIII. törvény a Magyar Köztársaság 2010. évi költségvetésének végrehajtásáról, a 2012. évi CCIV. törvény Magyarország 2013. évi központi költségvetéséről, a 2012. évi CLV. törvény a Magyar Köztársaság 2011. évi költségvetéséröl szóló 2010. évi CLXIX. törvény végrehajtásáról. 